\title{
The exchange of dissolved nutrients between the water column and substrate pore-water due to hydrodynamic adjustment at seagrass meadow edges: A flume study
}

\author{
A. Adhitya, ${ }^{* 1,6}$ A.M. Folkard, ${ }^{2}$ L. L. Govers, ${ }^{3,4,5}$ M. M. van Katwijk, ${ }^{3}$ H. H. de longh, ${ }^{6,7}$ P. M. J. Herman, ${ }^{1}$ \\ T.J. Bouma*1,5 \\ ${ }^{1}$ NIOZ Royal Netherlands Institute for Sea Research, Department of Estuarine and Delta Systems, and Utrecht University, \\ Yerseke, The Netherlands \\ ${ }^{2}$ Lancaster Environment Centre, University of Lancaster, Lancaster, U. K. \\ ${ }^{3}$ Department of Environmental Science, Institute for Water and Wetland Research, Radboud University Nijmegen, Faculty of \\ Science, Nijmegen, The Netherlands \\ ${ }^{4}$ Department of Aquatic Ecology and Environmental Biology, Institute for Water and Wetland Research, Radboud University \\ Nijmegen, Faculty of Science, Nijmegen, The Netherlands \\ ${ }^{5}$ Conservation Ecology Group, Groningen Institute for Evolutionary Life Sciences, University of Groningen, Groningen, The \\ Netherlands \\ ${ }^{6} \mathrm{CML} /$ Conservation Biology, Institute of Environmental Sciences, Van Steenis gebouw Einsteinweg, Leiden, The Netherlands \\ ${ }^{7}$ Department Evolutionary Biology, Antwerpen, Belgium
}

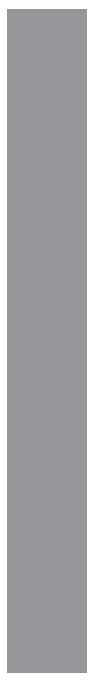

\begin{abstract}
Seagrasses need dissolved nutrients to maintain their productivity through uptake processes, from substrate pore-water via their roots and/or from the water column via their leaves. Here, we present the first study of exchanges of dissolved nutrients between pore water and the water column in the vicinity of seagrass canopies. We address the following research questions, using a laboratory flume experiment: (1) How does solute exchange between the water column and substrate pore water vary spatially within seagrass patches? (2) How does seagrass leaf length affect this solute exchange? (3) How does the measured rate of solute exchange compare with seagrasses' rates of uptake of dissolved nutrients? Our results indicate that solute intrusion from the water column into the substrate pore water is highest in the area around seagrass patches' leading edges, where flow deceleration is strongest, and decreases approximately linearly with downstream distance into the patch. The decrease in measured flow speed in the canopy fits well the predictions of previously reported models of arrays of rigid obstacles. The length of the region in which the concentration of solute that has infiltrated into the substrate at the upstream end of the seagrass patches is similar to the length scale predicted from model estimates of infiltration rate (based on the substrate permeability) and the length of time over 24-h runs. We conclude that the mechanism we identify only pertains near canopy edges, and therefore that other mechanisms must govern nutrient supply in the interior of seagrass meadows.
\end{abstract}

\section{Introduction}

Seagrass meadows are highly productive ecosystems that provide important services such as offering nursery and other habitats to a wide range of marine species (Kennedy et al. 2010; Short et al. 2011; Cullen-Unsworth et al. 2013), contributing to shoreline protection by reducing erosion (Hendricks et al. 2007; Christiansen et al. 2013) and attenuating wave and current energy (Pujol and Nepf, 2012; Paul et al. 2012). In recent decades, seagrass meadows have decreased globally at an alarming rate (Cambridge et al. 1986; Morris

*Correspondence: Tjeerd.Bouma@NIOZ.NL and Achmad.Adhitya@NIOZ.NL and Virnstein, 2004; Waycott et al. 2009). This decline has often been linked to problems with water quality: either enhanced turbidity (van der Heide et al. 2007, Carr et al. 2010) or hypertrophic nutrient concentrations causing algae blooms (Gacia and Duarte, 2001; Apostolaki et al. 2010). In contrast to our knowledge about threats associated with high nutrient concentrations, we have a poor understanding of how seagrasses can flourish in the low nutrient (oligotrophic) environments in which they are often found, particularly in many tropical regions. 
Contrary to many terrestrial macrophytes, seagrasses are poor at resorbing nitrogen from senescing leaves, resulting in high N-losses due to leaf detachment (Stapel et al. 1996; Romero et al. 2006). The high productivity and leaf-loss of seagrasses result in a nutrient paradox (Hemminga et al. 1999; Reyes and Sansón, 2001): How can seagrasses maintain their productivity if so much of their nutrients is lost via senescing leaves? Possible solutions to this paradox are that the leaves degrade within the meadow, enabling re-uptake of their nutrients by the seagrass (Peduzzi and Herndl, 1991; Apostolaki et al. 2010); trapped suspended particles may similarly contribute (Hendricks et al. 2007; Duarte et al. 2011; Kennedy et al. 2010) or seagrasses can take up dissolved organic nitrogen (DON) from sources within the bed sediment (Barron et al. 2006, Vonk et al. 2008, Van England et al. 2011). Whereas these latter studies show that DON may provide an important $\mathrm{N}$ source to seagrass roots, we lack insight into how DON, or suspended matter, enters the substrate beneath seagrass meadows.

For bare, permeable, sandy sediment substrates, several studies have shown high rates of water exchange between the water column above the substrate and the pore water within it, which may cause biological and chemical modifications of the pore water via advection of suspended or dissolved matter (Huettel and Gust, 1992; Huettel and Rusch, 2000). Such fluxes are generally caused by pressure gradients, which may be due to wave propagation causing pressure oscillations at the sediment surface (Webb and Theodor, 1972; Shum, 1992; Precht and Huettel, 2004) or to currents' interactions with seabed topography (Huettel and Webster, 2001). For example, a local vertical pressure gradient of 100 $\mathrm{Pa} \mathrm{m}^{-1}$, caused by flow encountering a small rise in the bed, is enough to force water several centimeters into the sediment and draw pore water from more than $0.1 \mathrm{~m}$ beneath the sediment surface into the water column (Huettel et al. 1998).

If advective exchange between the water column and pore water (referred to hereinafter as "pore water exchange") also occurs within seagrass meadows, it could provide an important supply of DON to seagrass roots, which are particularly good at taking up DON (Evrard et al. 2005; Vonk et al. 2008; Van England et al. 2011). Little is known about this phenomenon in the presence of seagrass. Laboratory flume experiments have been reported that have provided models of flow adjustments at the upstream end of vegetation(-mimic) canopies (Folkard 2005; Tanino and Nepf, 2008; Chen et al. 2013). The general pattern observed in these experiments is that, on encountering such a canopy, the flow adjusts to the canopy's presence such that part of it is deflected upwards and travels at accelerated speeds over the top of the canopy, and part travels at decelerated speeds through the canopy. However, there is also a third possible flow path-just as the flow can be deflected over the canopy, it can also be deflected beneath it, into the permeable substrate. This mechanism is analogous to the enhancement of infiltration by pressure gradients around seabed topography discussed by Huettel et al. (1998) and would cause changes in the pore water exchange rate: we would expect enhanced infiltration from the water into the substrate while the in-canopy flow decelerates as a result of the presence of the canopy. Although other laboratory experimental studies have investigated the influence of seagrass canopy structure on solute uptake rates from the water column (Thomas et al. 2000; Morris et al. 2008), this hydrodynamic mechanism of enhanced pore water exchange, which would be expected to affect nutrient supply to seagrass roots, has not previously been investigated. Hence, here we used laboratory flume experiments to elucidate and quantify pore water exchange in the presence of patches of seagrass mimics. Since the geometric configuration of the seagrass canopy might be expected to be a primary factor in determining the magnitude of this phenomenon, we investigated the influence on it of different canopy heights (leaf lengths).

\section{Material and methods}

To measure the effect of seagrass canopies on pore water exchange in a spatially explicit way, we carried out experiments in a race track laboratory flume at the Royal Netherlands Institute for Sea Research (NIOZ) in Yerseke (Fig. 1a; details in Bouma et al. 2009). Coral sand collected from a natural, oligotrophic seagrass meadow in Indonesia (median grain size $d_{50}=5.8 \times 10^{-4} \mathrm{~m}$; permeability $1.6 \times 10^{-11} \mathrm{~m}^{2}$ ) was placed into the test section of the flume $(2 \mathrm{~m}$ long $\times$ $0.6 \mathrm{~m}$ wide), which had a false floor to a depth of $0.15 \mathrm{~mm}$, such that the top of the sand layer was flush with the flume bed. The whole flume was then filled with fresh water to a height $H=0.40 \mathrm{~m}$ above the sand surface. We measured the pore water content of the sand used in the flume test section by taking replicate samples of $0.5 \mathrm{~L}$ of the sand, placing them in a $1 \mathrm{~L}$ graduated cylinder and covering them with water. We took the volume indicated by the surface of the sand in the cylinder as the combined volume of the sand and pore water, and subtracted the $0.5 \mathrm{~L}$ volume of the sand from this to give the pore water volume. The water volume thus measured was $0.189 \pm 0.0041$ (mean +1 sd; $n=5)$, giving a porosity (water:total volume ratio) of $0.274 \pm 0.004$ (volumetric sand: water ratio $2.65 \pm 0.05$, volumetric water:sand ratio $0.378+0.006)$.

To simulate the seagrass, we used polyethylene mimics, a generally accepted approach in flume studies of hydrodynamic processes within seagrass beds (Nepf \& Vivoni, 2000; Folkard, 2005; Bouma et al. 2009). The polyethylene used had modulus of elasticity $E=1.09 \pm 0.425 \times 10^{7} \mathrm{Nm}^{-2}$ $(N=6)$. The design of our mimics was based on field observations of Thalassia hemprichii at the same location in Indonesia from where the sediment was taken. Two sets of mimics were created. The first (the "long-leaved" mimics) consisted 
a. Race Track Flume

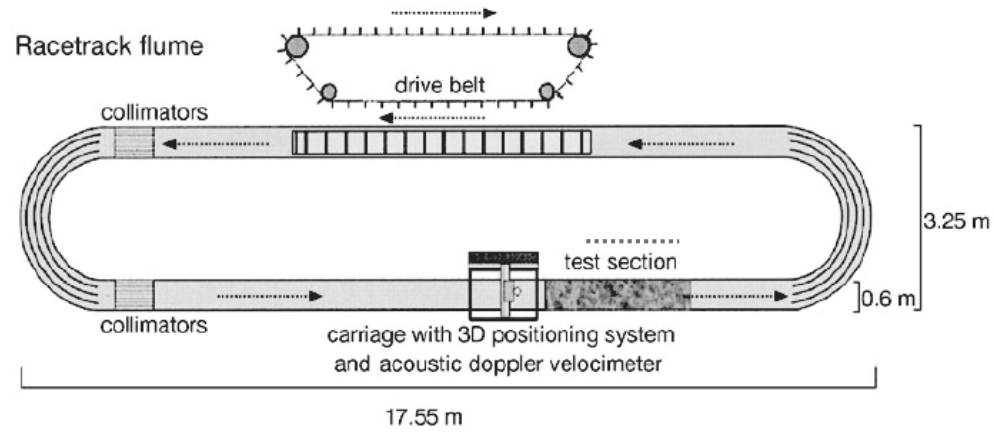

b. Seagrass Setup and Hydrodynamic Scheme

sand without seagrass seagrass meadow sand without seagrass

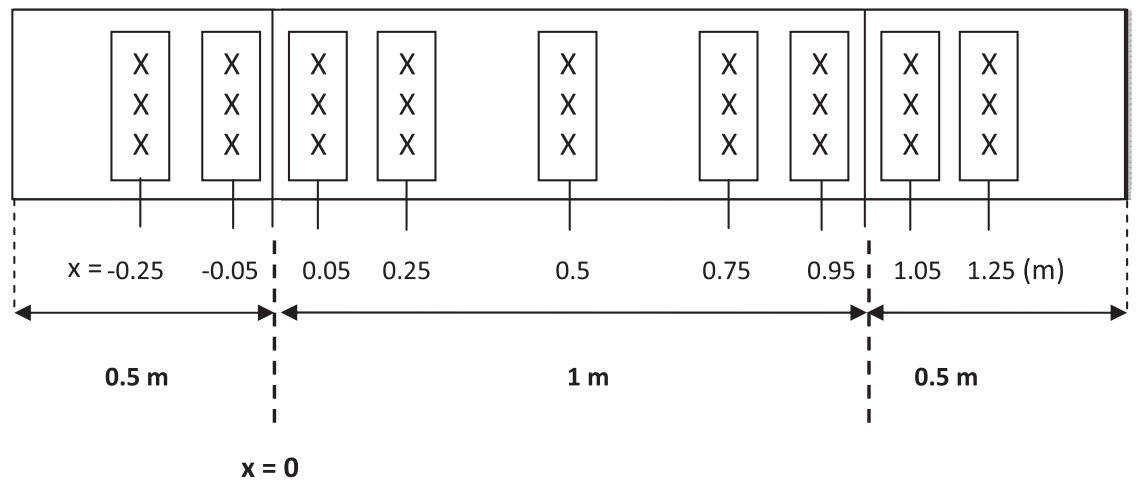

Fig. 1. (a) Plan view of the racetrack flume tank at NIOZ, Yerseke; (b) Plan view of the simulated seagrass meadow placed in the test section of the flume, showing locations of measurements of nutrient penetration. [Color figure can be viewed at wileyonlinelibrary.com]

of four leaves per shoot, each leaf being $0.14 \mathrm{~m}$ long, $0.01 \mathrm{~m}$ wide and $0.0001 \mathrm{~m}$ thick. These leaves were attached to $0.08 \mathrm{~m}$-long sheaths that were inserted into the coral sand in the flume, so that the top of the sheath was level with the sand surface, and the leaves protruded above the sand into the water column. The second (the "short-leaved" mimics) consisted of two leaves per shoot, each being $0.1 \mathrm{~m}$ long, $0.01 \mathrm{~m}$ wide and $0.0001 \mathrm{~m}$ thick. These leaves were attached to $0.05 \mathrm{~m}$-long sheaths, which were similarly inserted into the sand such that their tops were flush with the sand surface. These sheaths clearly simplify the belowground structure of seagrass roots and rhizome systems, but we assume that this does not affect our ability to elucidate the mechanism of pore water exchange. In both cases, a $1 \mathrm{~m}$ long patch of plant mimics in a uniform spatial configuration with a density of 722 shoots $\mathrm{m}^{-2}$ (c.f. shoot densities observed in natural Thalassia meadows of 48-1888 shoots $\mathrm{m}^{-2}$, Lewis, 1984; Tomasko and Lapointe, 1991; Barry et al. 2013) was fabricated. This was placed in the flume test section, filling the whole $0.6 \mathrm{~m}$ width of the flume, and leaving $0.5 \mathrm{~m}$ of bare sand both upstream and downstream (Fig. 1b). Since the upstream adjustment of the flow occurs over a distance comparable to the meadow height (i.e. at most $0.14 \mathrm{~m}$ for the long leaves, and $0.1 \mathrm{~m}$ for the short leaves) this length of bare sand should capture any variations in solute exchange due to such flow adjustments (Folkard, unpublished data). We did not test a control case with no seagrass, as we assumed that there would be no systematic variation in solute exchange in such a case, and that the rate of exchange would be comparable to that measured $0.25 \mathrm{~m}$ upstream of the canopy in these experiments, due to the lack of variation in bottom conditions. Along-flume locations are identified using the coordinate $x$, where $x=0$ is the upstream end of the patch (positive downstream), and vertical locations using the coordinate $z$, where $z=0$ is the surface of the sand (positive upwards). The penetration of nutrients into the sediment was detected using bromide as a conservative proxy tracer. Tracers are commonly used for characterizing flows in surface waters, and estimating groundwater discharges (Replogle et al. 1968; Finkner and Gilley, 1986). Bromide is suitable for usage in surface water (Smith and Davis., 1974; Gilley et al. 1990), and for determining hydraulic parameters both in the field (Owens et al. 1985; Lin et al. 2003), and laboratory (Glud et al. 1994; 
Foster et al. 1999; Rasheed et al. 2003). Here, bromide was added into the surface water at a concentration $\left[\mathrm{Br}^{-}\right]_{t}$ of $0.1 \mathrm{~kg} \mathrm{~m}^{-3}$.

A current with a mean speed of $0.3 \mathrm{~m} \mathrm{~s}^{-1}$ was passed around the flume, representing typical hydrodynamic conditions observed in shallow seagrass meadows (Palmer, 1988; Verduin and Backhaus, 2000). After $24 \mathrm{~h}$ exposure of the sediment substrate to the flow of this bromide-seeded water, cores of the substrate were extracted to determine the amount of bromide that had penetrated into them. The $24 \mathrm{~h}$ period was chosen to ensure that the bromide was wellmixed in the water column, but was otherwise solely for logistical convenience. The cores were extracted using 0.11 syringes with their narrow tips cut off, giving cores of approximately $0.05 \mathrm{~m}$ in diameter. At each location, the core was extracted by positioning the syringe vertically with the base of the plunger flush with the sediment surface, then pushing the sleeve of the syringe into the sediment whilst keeping the plunger stationary. When the syringe was lifted away, it took with it a core of sediment that retained the relative position of sediment and pore water within itself, which was immediately stored at $-20^{\circ} \mathrm{C}$. Cores were taken at three random replicate cross-flume locations at each of nine along-flume locations covering upstream of, within, and downstream of the patch: $x=-0.25,-0.05$, $0.05,0.25,0.5,0.75,0.95,1.05$ and $1.25 \mathrm{~m}$ (Fig. 1b). For analysis, a 0.02 m-thick section was sliced from the top of each core, and this was sliced in half, to enable measurements of pore water in two layers $(0-0.01 \mathrm{~m}$ and 0.01$0.02 \mathrm{~m})$. This approach followed that of Reimers et al.'s (2004) in situ measurements of iodide in sediments with similar grain size. The layers were defrosted and centrifuged for 2 minutes at $1000 \mathrm{rpm}$ to separate the pore water from the sediment. The bromide concentrations in the pore water $\left[\mathrm{Br}^{-}\right]_{c}$ were measured using high performance liquid chromatography (HPLC), and expressed, following Peralta et al. (2008), as relative bromide concentration $\left(\left[\mathrm{Br}^{-}\right]_{\mathrm{rel}}, \%\right)$, i.e. their ratio to $\left[\mathrm{Br}^{-}\right]_{t}$, the bromide concentration in water column:

$$
\left[\mathrm{Br}^{-}\right]_{\text {rel }}=\frac{\left[\mathrm{Br}^{-}\right]_{\mathrm{C}}}{[\mathrm{Br}]_{t}^{-}} \cdot 100 \%
$$

Velocity measurements were made using a Vectrino Acoustic Doppler Velocimeter (ADV, Nortek AS, Rud, Norway) at the same along-flume positions at which sediment samples were taken (Fig. 1b). At each location, velocities were measured at heights $Z_{1}$ to $Z_{\mathrm{n}}=0.005,0.03,0.07,0.095,0.115,0.13,0.15$, $0.18,0.27$ and $0.31 \mathrm{~m}$. All of these measurements were made at mid channel, to minimize wall effects. At each measurement point, velocity was recorded for 120 seconds at $10 \mathrm{~Hz}$. The height of the deflected canopy, h, was measured for every along-flume location at which velocity was measured, using a ruler attached to the side of the flume.
Variations in the mean flow speed $\left(\mathrm{U}, \mathrm{m} \mathrm{s}^{-1}\right)$ were calculated separately for the regions above $\left(U_{\mathrm{a}}\right)$ and within $\left(U_{\mathrm{b}}\right)$ the seagrass canopy, as averages of the flow speed measurements at each measurement height $z_{\mathrm{i}}$, weighted by the distance between adjacent measurement heights:

$$
\begin{aligned}
U_{a} & =\frac{1}{(H-h)}\left\{U\left(z_{j}\right)\left(\frac{z_{j}+z_{j+1}}{2}-h\right)\right. \\
& \left.+\sum_{i=j+1}^{n-1} \mathrm{U}\left(z_{\mathrm{i}}\right)\left(\frac{z_{i}+z_{i+1}}{2}-\frac{z_{i-1}+z_{i}}{2}\right)+U\left(z_{n}\right)\left(H-\frac{z_{n-1}+z_{n}}{2}\right)\right\} \\
U_{b} & =\frac{1}{h}\left\{U\left(z_{1}\right)\left(\frac{z_{1}+z_{2}}{2}\right)\right. \\
& \left.+\sum_{i=2}^{j-2} \mathrm{U}\left(\mathrm{z}_{\mathrm{i}}\right)\left(\frac{z_{i}+z_{i+1}}{2}-\frac{z_{i-1}+z_{i}}{2}\right)+U\left(z_{j-1}\right)\left(h-\frac{z_{j-2}+z_{j-1}}{2}\right)\right\}
\end{aligned}
$$

where $z_{j}$ is the first measurement point above the top of the canopy and $n$ is the total number of measurement points in the profile.

\section{Results}

\section{Hydrodynamic flow adjustment due to the canopy}

The flow was slower within both the long and short seagrass meadows than above them (Fig. 2). Flow within the seagrass canopies gradually decelerated with distance away from leading edge, implying (due to conservation of mass) that flow within the canopies had a component moving upwards and out of the canopies. The horizontal velocity gradient (rate of reduction of downstream flow speed) was larger in the long seagrass than in the short seagrass (Fig. 3). The adjustment length $\left(X_{\mathrm{D}}\right)$ over which this reduction in incanopy speed takes place, and the mean in-canopy flow speed achieved at the end of the adjustment $\left(U_{1}\right)$ are predicted by Chen et al. (2013), for canopies of rigid obstacles, to be given by

$$
\begin{gathered}
X_{D}=\frac{3(1-\phi)}{C_{D} a}\left(1+2.3 C_{D} a h\right) \\
U_{1}=\frac{U}{1-\frac{h}{H} \phi+\sqrt{\frac{C_{D} a h}{2 C(1-\phi)}\left(\frac{H-h}{H}\right)^{3}}}
\end{gathered}
$$

where $\phi$ is the canopy solid volume fraction, $C_{\mathrm{D}}$ the canopy drag coefficient, a the frontal area per canopy volume, and $C=K_{\mathrm{c}}\left(\delta_{\mathrm{e}} / H\right)^{1 / 3}$, where $K_{\mathrm{c}}$ is an empirical coefficient which Chen et al. (2013) find to be $0.07 \pm 0.02$ (here, we use 0.07) and $\delta_{\mathrm{e}}$ is the penetration length scale of vortices in the overflow into the top of the canopy, which we calculate (following Nepf et al. 2007) as $0.23 / C_{\mathrm{D}}$ a. As stated above, the plant mimics used had a density of 722 shoots $\mathrm{m}^{-2}$, there were two (four) leaves per shoot in the short (long) leaved cases, and each leaf was $0.01 \mathrm{~m}$ wide and $0.0001 \mathrm{~m}$ thick. Thus, 

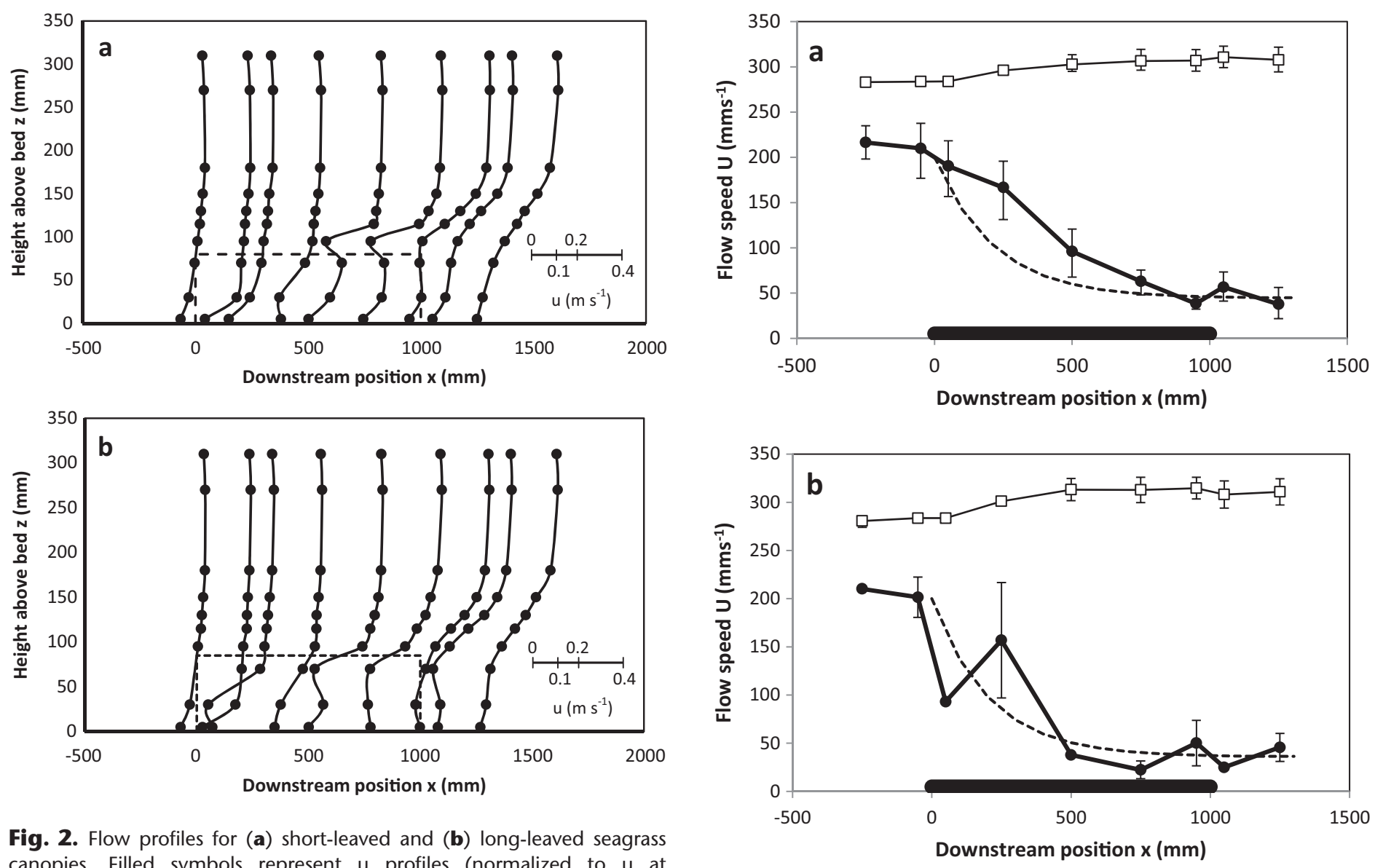

Fig. 2. Flow profiles for (a) short-leaved and (b) long-leaved seagrass canopies. Filled symbols represent $u$ profiles (normalized to $u$ at $z=0.3 \mathrm{~m}$ ). The dotted lines indicate the location of the canopy where long-leaved seagrass bent to similar height as short-leaved seagrass height. The velocity magnitudes are indicated by the scale bars.

the solid volume fraction for the short-leaved canopy was $\phi=722 \times 2 \times 0.01 \times 0.001=0.0014$ and for the long-leaved canopy was 0.0028 . There is uncertainty, however, about the appropriate value of $C_{\mathrm{D}}$ for our canopies. Tanino and Nepf (2008) have investigated $C_{\mathrm{D}}$ for arrays of solid cylinders, and numerous studies have reported values of $C_{\mathrm{D}}$ for a wide range of-mainly terrestrial-flexible vegetation (see $\mathrm{Wu}$ et al. 1999), but drag coefficient values for seagrass canopies are not well known, and are likely to be highly dependent on canopy structure (Peterson et al. 2004). We therefore use our data and Chen et al.'s equations to back calculate values for $C_{\mathrm{D}}$ for our canopies. Doing this give values of $C_{\mathrm{D}}=1.5$ for the short-leaved canopy and 1.7 for the long-leaved canopy. Using these values in (4) and (5) gives $X_{\mathrm{D}}=0.66 \mathrm{~m}$ and $U_{1}=0.036 \mathrm{~ms}^{-1}$ for the short-leaved canopy and $X_{\mathrm{D}}=0.65 \mathrm{~m}$ and $U_{1}=0.034 \mathrm{~ms}^{-1}$ for the long-leaved canopy. These provide a predicted velocity decay that fits our data in the longleaved case reasonably well, but in the short-leaved case, our data shows more of a linear decay in in-canopy flow speed (Fig. 3) rather than the exponential decay assumed by Chen

Fig. 3. Downstream development of the mean flow speeds over the canopy $\left(U_{a}\right.$; clear symbols) and within the canopy ( $U_{b}$; filled symbols) for (a) short-leaved and (b) long-leaved seagrass canopies. The dotted line indicates the predictions of the model of Chen et al. (2013) - see text for details. The thick black lines indicate the location of the seagrass canopy.

et al. and observed elsewhere for arrays of rigid obstacles (Belcher et al. 2003).

\section{Bromide penetration in the pore-water}

Despite the large degree of variation in the data, Fig. 4 shows that the relative bromide concentration $\left[\mathrm{Br}^{-}\right]_{\text {rel }}$ was highest around the leading edge of canopy in both depth layers in both the short- (Fig. 4a) and long-leaved (Fig. 4b) canopies. The horizontal distance over which the solute is predicted to be able to travel through the substrate in the $24 \mathrm{~h}$ for which the experiment was run can be predicted from the infiltration speed. This can be calculated, following Nepf and Koch (1999), as

$$
V_{D}=\frac{K U^{2}}{g d}
$$

where $K$ is the sediment permeability $\left(1.6 \times 10^{-11} \mathrm{~m}^{2}\right)$, and $\mathrm{d}$, the distance over which the flow deceleration at the front 

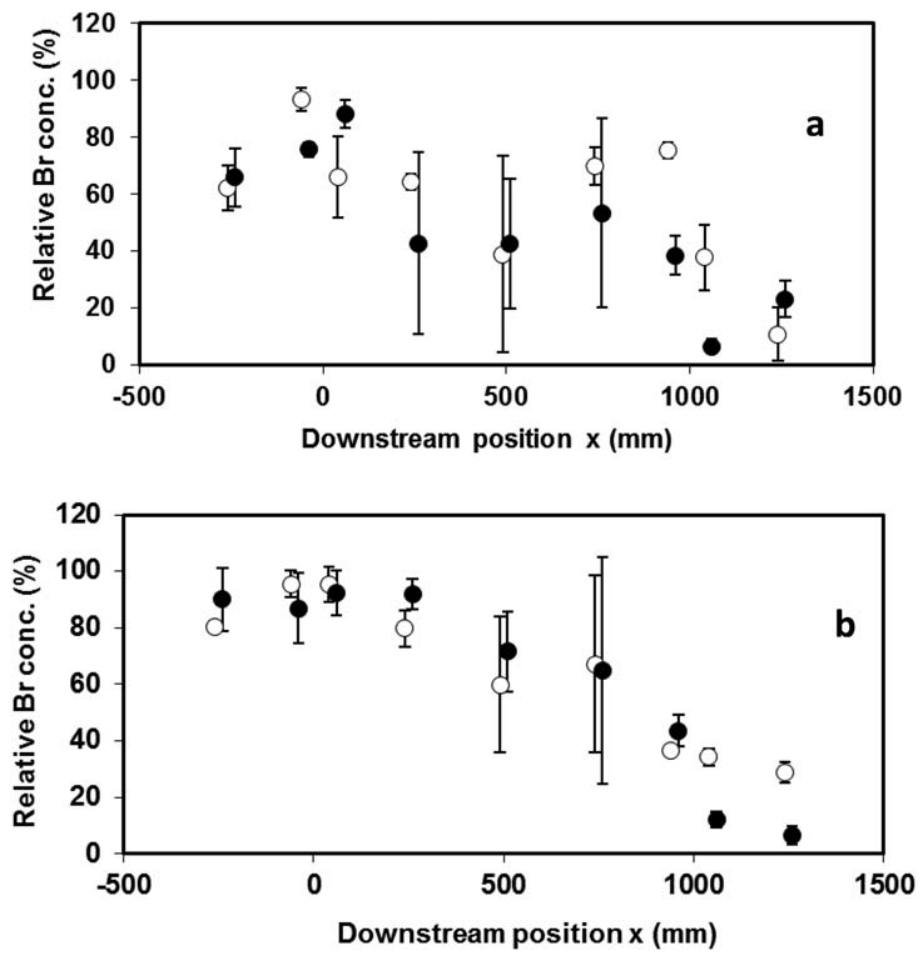

Fig. 4. Relative bromide concentration, as defined in equation (1), in the pore water measured after $24 \mathrm{~h}$ of running the flow, for (a) the short-leaved seagrass canopy; and (b) the long-leaved seagrass canopy. Clear symbols represent relative bromide concentration in $0.01 \mathrm{~m}$ depth; filled symbols represent relative bromide concentration in $0.02 \mathrm{~m}$. Error bars show standard deviation of samples measured at the three parallel locations for each $x$-position shown in Fig. $1 \mathrm{~b}$.

end of the canopy, is taken (from Fig. 3) to be approximately $X_{\mathrm{D}}=0.65 \mathrm{~m}$. This gives $V_{\mathrm{D}}=2.22 \times 10^{-6} \mathrm{~m} \mathrm{~s}^{-1}$, which over $24 \mathrm{~h}$ gives a horizontal penetration distance of $0.19 \mathrm{~m}$, which is of the same order of magnitude as the length over which the maximum levels of measured bromide concentration in the substrate are sustained, in both of the canopies at both depths.

The rate at which the bromide infiltrates into the substrate can be compared to the rate of uptake of nutrients by seagrasses. The value of $V_{\mathrm{D}}$ calculated above implies a volumetric rate of water infiltration of $2.94 \times 10^{-6} \mathrm{~m}^{3} \mathrm{~s}^{-1}$ per $\mathrm{m}^{2}$ of bed surface area. If we assume that the concentration of dissolved, bioavailable nitrogen in coastal waters is 0.00005-0.0005 $\mathrm{g} \mathrm{L}^{-1}$ (Cozzi and Giani, 2007), this would imply $0.00053-0.0053 \times 10^{-3} \mathrm{~kg} \mathrm{~N}\left(\mathrm{~m}^{2} \text { sediment surface }\right)^{-1}$ $\mathrm{h}^{-1}$ of dissolved nitrogen exchange between the water column and the sediments. Rates of nitrogen uptake by seagrasses vary greatly but a typical value is $5 \mu \mathrm{mol}$ (g dry weight $)^{-1} \mathrm{~h}^{-1}$ i.e. $70 \mu \mathrm{g} \mathrm{N}$ (g dry weight) ${ }^{-1} \mathrm{~h}^{-1}$ (Vonk et al. 2008). Touchette and Burkholder (2000) give a range of 5-270 $\mu \mathrm{g} \mathrm{N}$ (g dry weight) ${ }^{-1} \mathrm{~h}^{-1}$ for ammonium uptake. If the density of real seagrass is estimated as $910 \mathrm{~kg} \mathrm{~m}^{-3}$
(Folkard, 2005), then the short-leaved canopy used here represents a dry weight seagrass mass of $0.13 \mathrm{~kg}\left(\mathrm{~m}^{2}\right.$ sediment bed surface area) ${ }^{-1}$, and the long-leaved canopy $0.325 \mathrm{~kg}$ $\left(\mathrm{m}^{2} \text { sediment bed surface area }\right)^{-1}$. This implies that the solute exchange rate can be written as 4.1-41 $\mu \mathrm{g} \mathrm{N}$ (g dry weight $)^{-1} \mathrm{~h}^{-1}$ for the short-leaved seagrass, and 1.6-16 $\mu \mathrm{g} \mathrm{N}$ (g dry weight $)^{-1} \mathrm{~h}^{-1}$ for the long-leaved seagrass. These values are the same order of magnitude as typical range of uptake rates of nitrogen by seagrasses, if arguably towards the lower end of that range.

\section{Discussion}

Effect of the seagrass canopy on hydrodynamics

Our experiments demonstrate the well-established pattern of flow adjustment at the upstream end of a submerged vegetation canopy (Folkard, 2005; Tanino and Nepf, 2008; Chen et al. 2013), whereby part of the flow travels at accelerated speeds over the top of the canopy, and part travels at decelerated speeds through the canopy. They also indicate the third element of flow that we theorize above - the enhancement of infiltration from the water column into the substrate while the in-canopy flow decelerates as a result of the presence of the canopy. This flow is negligible in terms of water discharge (in these experiments, its velocity scale is $\sim 10^{-6} \mathrm{~ms}^{-1}$, compared to $\sim 10^{-2} \mathrm{~ms}^{-1}$ for the canopy through-flow and $\sim 10^{-1} \mathrm{~ms}^{-1}$ for the overflow) but, as discussed below, important for nutrient budgets.

The magnitude of the reduction in flow speed observed in both the long- and short-leaved cases here is in good agreement with the predictions of Chen et al. (2013), which are derived from a two-layer flow model of flows through arrays of rigid obstacles (c.f. the flexible obstacles used here). This model assumes that the layers are connected via turbulent stresses in the shear zone at the top of the canopy which are assumed to scale on the square of the velocity difference between the layers and the length scale of the vortices within the shear zone. The latter, in turn, are assumed to scale on the reciprocal of the product of the canopy drag coefficient $\left(C_{\mathrm{D}}\right)$ and frontal area per unit volume $(\mathrm{a})$. The adjustment length measured in these experiments, over which this reduction in flow speed $\left(X_{\mathrm{D}}\right)$ occurs, fits well the predictions of Chen et al. (2013) for our long-leaved canopy (Fig. 3b), but appears to be slower, and more linear rather than exponential, in our short-leaved canopy. Reasons for this are unclear; one possibility is that relatively sparse canopies of flexible obstacles allow preferential flow paths to be set up that lead to a more gradual flow decay rate at the start of the canopy (where the flow is faster and more able to deflect the obstacles). But this is purely speculative, and the distinction between flow decay in canopies of rigid and flexible obstacles suggested by our data requires further investigation. 
Effects of hydrodynamic adjustment to the seagrass canopy on solute exchange

The horizontal length scale over which the highest levels of bromide concentration within the sediment cores persists into the canopy $(\sim 0.2 \mathrm{~m})$ matches well that predicted from the assumption that the solute exchange between the water column and the substrate results from the infiltration of the flow into the substrate due to its deceleration by the canopy. This supports the hypothesis that the enhanced solute exchange is due to increased flow infiltration as a result of the deceleration of the in-canopy flow. The lack of distinction between the bromide concentrations in the $0-0.001 \mathrm{~m}$ and 0.001-0.002 $\mathrm{m}$ depth cores indicates that the infiltrating water spreads more deeply than these depths. In the present study, we concentrated on the horizontal extent of nutrient delivery to the substrate. The relationship between the depth of infiltration and the depth of seagrass roots is also likely to be important for determining seagrasses' nutrient uptake rates, and requires further investigation. The variability in measured bromide concentrations (Fig. 4) is quite high, and as a result there is no clear difference in them between the short- and long-leaved cases studied here.

\section{Effects of solute exchange on seagrass canopy}

The fact that our estimates of nutrient exchange rate are in the same range of orders of magnitude as the rate of nutrient uptake by seagrasses indicates that nutrient exchange between the water column and sediment at seagrass canopy edges is an important process for determining seagrass nutrient uptake in these regions. Seagrasses can take up dissolved nutrients from both pore water and the water column (Stapel et al. 1996, Hemminga et al. 1999), but pore water nutrient concentrations are generally higher (Okubo et al. 2002; Larned et al. 2004), especially in the oligotrophic waters typically found in tropical seagrass environments. This implies that pore water nutrient concentrations, and thus the rates of infiltration of water into the sediment are an important determinant of seagrass growth rates at the upstream edges of seagrass canopies. By extension, one can hypothesize that there is likely to be exfiltration of relatively nutrient-rich interstitial water from the sediment into the water column at the downstream end of canopies, where the near-bed water column pressure is reduced. This, therefore, is likely to be an important mechanism for replenishment of nutrients in the water column. We conclude from this study that the nutrient transfer rate from the water column to the pore water is determined primarily by the infiltration of the flow into the substrate due to its deceleration by the canopy-as well as the ambient nutrient concentration (Nishihara and Ackerman, 2006), which we have not considered here. This has the effect of causing pore water dissolved nutrient concentrations to decrease with increasing distance from seagrass canopy edges (over a distance of $\sim 0.5$ to $1 \mathrm{~m}$ in our study). This finding has important ecological implications, as it implies favorable nutrient conditions for clonal expansion at the edges of seagrass patches, which can increase the seagrass growth rate and thus facilitate patch and meadow expansion. However, this also raises the question of how nutrients can be delivered to pore water in the interior of seagrass meadows, where our results suggest nutrient concentrations would be very low if they were purely determined by the mechanism we have identified as being important here, as there is no flow deceleration here. Future studies are therefore required to identify the mechanisms that ensure sufficient nutrient supply to seagrasses in the interior of seagrass meadows.

\section{References}

Apostolaki, E., M. Holmer, N. Marba, and I. Karakassis. 2010. Degrading seagrass (Posidonia oceanica) ecosystems: a source of dissolved matter in the Mediterranean. Hydrobiologia. 649: 13-23. doi:10.1007/s10750-010-0255-2

Barron, C., J. J. Middelburg, and C. M. Duarte. 2006. Phytoplankton trapped within seagrass (Posidonia oceanica) sediments are a nitrogen source: An in situ isotope labeling experiment. Limnol. Oceanogr. 51: 1648-1653. doi: 10.4319/1o.2006.51.4.1648

Barry, S. C., T. K. Frazer, and C. A. Jacoby. 2013. Production and carbonate dynamics of Halimeda incrassate (Ellis) Lamouroux altered by Thalassia testudinum Banks and Soland ex Konig. J. Exp. Mar. Biol. Ecol. 444: 73-80. doi: 10.1016/j.jembe.2013.03.012

Belcher, S. E., N. Jerram, and J. C. R. Hunt. 2003. Adjustment of a turbulent boundary layer to a canopy of roughness elements. J. Fluid Mech. 488: 369-398. doi:10.1017/ S0022112003005019

Bouma, T. J., M. et al. 2009. Effects of shoot stiffness, shoot size and current velocity on scouring sediment from around seedlings and propagules. Mar. Ecol. Prog. Ser. 388: 293-297. doi:10.3354/meps08130

Cambridge, M. L., A. W. Chiffings, C. Brittan, L. Moore, and A. J. McComb. 1986. The loss of seagrass in cockburn sound, western Australia II. possible causes of seagrass decline. Aquatic Bot. 24: 269-285. doi:10.1016/0304-3770(86)90062-8

Carr, J., P. D'Odorico, K. McGlathery, and P. Wiberg. 2010. Stability and bistability of seagrass ecosystems in shallow coastal lagoons: role of feedbacks with sediment resuspension and light attenuation. J. Geophys. Res. 115: G03011.

Chen, Z., C. Jiang, and H. M. Nepf. 2013. Flow adjustment at the leading edge of a submerged aquatic canopy. Water Resour. Res. 49: 5537-5551. doi:10.1002/wrcr.20403

Christiansen, M. J. A., J. van Belzen, P. M. J. Herman, M. M. van Katwijk, L. P. M. Lamers, P. J. M. van Leent, and T. J. Bouma. 2013. Low-Canopy Seagrass Beds Still Provide Important Coastal Protection Services. PLoS ONE. 8: e62413. doi:10.1371/journal.pone.0062413

Cozzi, S., and M. Giani. 2007. Determination of Organic Nitrogen and Urea, In L.M.L. Nollet and L.S.P. de Gelder 
[eds.], Handbook of water analysis 2nd edition. London: CRC Press.

Cullen-Unsworth, L. C., L. M. Nordlund, J. Paddock, S. Baker, L. J. McKenzie, and R. K. F. Unsworth. 2013. Seagrass meadows globally as a coupled social-ecological system: Implications for human wellbeing. Marine Pollut. Bull. 83: 387-397.

Duarte, C. M., H. Kennedy, N. Marba, and I. E. Hendricks. 2011. Assessing the capacity of seagrass meadows for carbon burial: Current limitations and future strategies. Ocean Coast. Manage. 51: 671-688.

Evrard, V., W. Kiswara, T. J. Bouma, and J. J. Middelburg. 2005. Nutrient dynamics of seagrass ecosystems: ${ }^{15} \mathrm{~N}$ evidence for the importance of particulate organic matter and root systems. Mar. Ecol. Prog. Ser. 295: 49-55. doi: 10.3354/meps295049

Finkner, S. C., and J. E. Gilley. 1986. Sediment and dye concentration effects on fluorescence. Appl. Eng. Agric. 2: 104-7. doi:10.13031/2013.26721

Folkard, A. M. 2005. Hydrodynamics of model Posidonia Oceanica patches in shallow water. Limnol. Oceanogr. 50: 1592-600 [Database]. doi:10.4319/lo.2005.50.5.1592

Foster, S., R. N. Glud, J. K. Gundersen, and M. Huettel. 1999. In situ study of bromide tracer and oxygen flux in coastal sediments. Est. Coast. Shelf Sci. 49: 813-827. doi:10.1006/ ecss.1999.0557

Gacia, E., and C. M. Duarte. 2001. Sediment retention by a mediterranean Posidonia oceanica meadow: the balance between deposition and resuspension. Estuar. Coast. Shelf Sci. 52: 505-514. doi:10.1006/ecss.2000.0753

Gilley, J. E., S. C. Finkner, J. W. Doran, and E. R. Kottwitz. 1990. Adsorption of bromide Tracers onto sediment. Appl. Eng. Ind. Agric. 6: 35-38. doi:10.13031/2013. 26341

Glud, R. N., J. K. Gundersen, B. B. Jorgensen, N. P. Revsbech, and H. D. Schulz. 1994. Diffusive and total oxygen uptake of deep sea sediments in the Eastern South Atlantic Ocean: in situ and laboratory measurements. Deep Sea Res. 41: 1767-1788. doi:10.1016/0967-0637(94)90072-8

Hemminga, M. A., N. Marba, and J. Stapel. 1999. Leaf nutrient resorption, leaf lifespan and the retention of nutrients in seagrass systems. Aquat. Bot. 65: 141-158. doi:10.1016/ S0304-3770(99)00037-6

Hendricks, I. E., T. Sintes, T. Bouma, and C. M. Duarte. 2007. Experimental assessment and modeling evaluation of the effects of seagrass ( $P$. oceanica) on flow and particle trapping. Mar. Ecol. Prog. Ser. 356: 163-173.

Huettel, M., and G. Gust. 1992. Solute release mechanisms from confined sediment cores in stirred benthic chambers and flume flows. Mar. Ecol. Prog. Ser. 82: 187-197. doi: 10.3354/meps082187

Huettel, M., and A. Rusch. 2000. Transport and degradation of phytoplankton in permeable sediment. Limnol. Oceanogr. 45: 534-549. doi:10.4319/lo.2000.45.3.0534
Huettel, M., and I. T. Webster. 2001. Porewater flow in permeable sediments. In Boudreau, B.P. and Jorgensen, B.B [eds.], The benthic boundary layer. New York: Oxford Univ. Press, 144-179.

Huettel, M., W. Ziebis, S. Forster, and G. W. Luther. III, 1998. Advective transport affecting metal and nutrient distributions and interfacial fluxes in permeable sediments. Geochim. Et Cosmochim. Acta. 62: 613-631. doi: 10.1016/S0016-7037(97)00371-2

Kennedy, H., J. Beggins, C. M. Duarte, J. W. Fourqurean, M. Holmer, N. Marbà, and J. J. Middelburg. 2010. Seagrass sediments as a global carbon sink: Isotopic constraints. Global Biogeochem. Cycles. 24: GB4026.

Kristensen, E., G. Penha-Lopes, M. Delefosse, T. Valdemarsen, C. O. Quintana, and G. T. Banta. 2012. What is bioturbation? The need for a precise definition for fauna in aquatic sciences. Mar. Ecol. Prog. Ser. 446: 285-302. doi:10.3354/meps09506

Larned, S. T., V. I. Nikora, and B. J. F. Biggs. 2004. Mass transfer-limited nitrogen and phosphorus uptake by stream periphyton: A conceptual model and experimental evidence. Limnol. Oceanogr. 49: 1992-2000. doi:10.4319/ lo.2004.49.6.1992

Lewis, F. G. 1984. Distribution of macrobenthic crustaceans associated with Thalassia, Halodule and bare sand substrate. Mar. Ecol. Prog. Ser. 19: 101-113. doi:10.3354/ meps019101

Lin, A. Y. C., J. F. Debroux, J. A. Cunninghan, and M. Reinhard. 2003. Comparison of Rhodamine-WT and bromide in the determination of hydraulic chracteristics of constructed wetlands. Ecol. Eng. 20: 75-88. doi:10.1016/ S0925-8574(03)00005-3

Madsen, O. S. 1978. Wave-induced pore pressures and effective stresses in a porous bed. Géotechnique. 28: 377-393. doi:10.1680/geot.1978.28.4.377

Morris, L. J., and R. W. Virnstein. 2004. The demise and recovery of seagrass in the Northern Indian River Lagoon, Florida. Estuaries. 27: 915-922. doi:10.1007/ BF02803418

Morris, E. P., Peralta, G. Brun, E. P. F. G. Van Duren, L. A. Bouma T. J. Perez-Llorens., and J. L. 2008. Interaction between hydrodynamics and seagrass canopy structure: Spatially explicit effects on ammonium uptake rates. Limnol. Oceanogr. 53: 1531-1539. doi:10.4319/1o.2008.53.4. 1531

Nepf, H. M., and E. W. Koch. 1999. Vertical secondary flows in submersed plant-like arrays. Limnol. Oceanogr. 44: 1072-1080. doi:10.4319/lo.1999.44.4.1072

Nepf, H. M., and E. R. Vivoni. 2000. Flow structure in depth limited, vegetated flow. J Geophys. Res. 105: 547-28. 557

Nepf, H. M., M. Ghisalberti, B. White, and E. Murphy. 2007. Retention time and dispersion associated with submerged aquatic canopies. Water Resour. Res. 43: W04422. doi: 10.1029/2006WR005362 
Nishihara, G. N., and J. D. Ackerman. 2006. The effect of hydrodynamics on the mass transfer of dissolved inorganic carbon to the freshwater macrophyte Valissneria americana. Limnol. Oceanogr. 51: 2734-2745. doi:10.4319/ 10.2006.51.6.2734

Okubo, A., J. D. Ackerman, and D. P. Swaney. 2002. Passive diffusion in ecosystems. In: Okubo, A. and Levin, S. (eds.) Diffusion and ecological problems: new perspectives. New York: Springer Verlag, pp. 31-106.

Owens, L. B., R. W. Van Keuren, and W. M. Edwards. 1985. Groundwater quality changes resulting from a surface bromide application to a pasture. J. Environ. Qual. 14: 543548. doi:10.2134/jeq1985.00472425001400040015x

Palmer, M. A. 1988. Epibenthic predators and marine meiofauna: separating predation, disturbance and hydrodynamic effects. Ecology. 69: 1251-1259. doi:10.2307/ 1941280

Paul, M., T. J. Bouma, and C. L. Amos. 2012. Wave attenuation by submerged vegetation: combining the effect of organism traits and tidal current. Mar. Ecol. Prog. Ser. 444: 31-41. doi:10.3354/meps09489

Peduzzi, P., and G. J. Herndl. 1991. Decomposition and significance of seagrass leaf litter (Cymodocea nodosa) for the microbial food web in coastal waters (Gulf of Trieste, Northern Adriatic Sea). Mar. Ecol. Prog. Ser. 71: 163-174. doi:10.3354/meps071163

Peralta, G., L. A. Van Duren, E. P. Morris, and T. J. Bouma. 2008. Consequences of shoot density and stiffness for ecosystem engineering by benthic macrophytes in flow dominated areas: a hydrodynamic flume study. Mar. Ecol. Prog. Ser. 368: 103-115. doi:10.3354/meps07574

Peterson, C. H., R. A. Luettich, Jr, F. Micheli, and G. A. Skilleter. 2004. Attenuation of water flow inside seagrass canopies of differing structure. Marine Ecol. Prog. Ser. 268: 81-92. doi:10.3354/meps 268081

Precht, E., and M. Huettel. 2004. Rapid wave-driven advective pore water exchange in a permeable coastal sediment. J. Sea. Res. 51: 93-107. doi:10.1016/j.seares.2003. 07.003

Pujol, D., and H. Nepf. 2012. Breaker-generated turbulence in and above seagrass meadow. Continental Shelf Res. 19. doi:10.1016/j.csr.2012.09.004

Rasheed, M., M. I. Badran, and M. Huettel. 2003. Influence of sediment permeability and mineral composition on organic matter degradation in three sediments from the Gulf of Aqaba, Red Sea. Estuar. Coast. Shelf. Sci. 57: 369384. doi:10.1016/S0272-7714(02)00362-1

Reimers, C. E., H. A. et al. 2004. In situ measurements of advective solute transport in permeable shelf sands. Continent. Shelf Res. 24: 183-201. doi:10.1016/j.csr.2003.1 0.005

Replogle, J. A., L. E. Meyers, and K. J. Brust. 1966. Flow measurements with fluorescent tracers. ASCE J. Hydraulics. Div. 5: 1-14.
Reyes, J., and M. Sansón. 2001. Biomass and production of the epiphytes on the leavesof Cymodocea nodosa in the Canary Islands. Botanica Marina. 44: 307-313.

Romero, J., K. S. Lee, M. Perez, M. A. Mateo, and T. Alcoverro. 2006. Nutrient dynamics in seagrass ecosystems. In Larkum, A.W.D., Orth, R.J. and Duarte, C.M. [eds.] Seagrasses: biology, ecology and conservation. New York: Springer, 227-254.

Short, F. T., B. et al. 2011. Extinction risk assessment of the world's seagrass species. Biol. Conserv. 144: 1961-1971. doi:10.1016/j.biocon.2011.04.010

Shum, K. T. 1992. Wave-induced advective transport below a rippled water-sediment interface. J. Geophys. Res. (Oceans). 97: 789-808. doi:10.1029/91JC02101

Smith, S. J., and R. J. Davis. 1974. Relative movement of bromide and nitrate through soils. J. Environ. Qual. 3: 152155. doi:10.2134/jeq1974.00472425000300020014x

Stapel, J., T. L. Aarts, B. H. M. van Duynhoven, J. D. de Groot, P. H. W. van den Hoogen, and M. A. Hemminga. 1996. Nutrient uptake by leaves and roots of the seagrass Thalassia hemprichii in the Spermonde Archipelago, Indonesia. Mar. Ecol. Prog. Ser. 134: 195-206. doi:10.3354/ meps134195

Tanino, Y., and H. M. Nepf. 2008. Laboratory investigation of mean drag in a random array of rigid, emergent cylinders. J. Hydraul. Eng. 134: 34-41. doi:10.1061/ (ASCE)0733-9429(2008)134:1(34)

Thomas, F. I. M., C. D. Cornelisen, and J. M. Zande. 2000. Effects of water velocity and canopy morphology on ammonium uptake by seagrass communities. Ecology. 81: 2704-2713. doi:10.1890/0012-9658(2000)081[2704:EOW$\mathrm{VAC}] 2.0 . \mathrm{CO} ; 2$

Tomasko, D. A., and B. E. Lapointe. 1991. Productivity and biomass of Thalassia testudinum as related to water column nutrient availability adn epiphyte levels: field observations and experimental studies. Mar. Ecol. Prog. Ser. 75: 9-17. doi:10.3354/meps075009

Touchette, B. W., and J. M. Burkholder. 2000. Review of nitrogen and phosphorus metabolism in seagrasses. J. Exp. Mar. Biol. Ecol. 250: 133-167. doi:10.1016/S00220981(00)00195-7

Van der Heide, T., T. J. et al. 2007. Positive feedbacks in seagrass ecosystems: implications for success in conservation and restoration. Ecosystems. 10: 1311-1322. doi:10.1007/ s10021-007-9099-7

Van Engeland, T., T. J. Bouma, E. P. Morris, F. G. Brun, G. Peralta, M. Lara, and J. J. Middelburg. 2011. Potential uptake of dissolved organic matter by seagrasses and macroalgae. Mar. Ecol. Prog. Ser. 471: 71-81.

Verduin, J. J., and J. O. Backhaus. 2000. Dynamics of plant-flow interactions for the seagrass Amphibolus antartica: field observations and model simulations. Estuar Coast. Shelf Sci. 50: 185-204. doi:10.1006/ecss. 1999.0567 
Vonk, J. A., J. J. Middelburg, J. Stapel, and T. J. Bouma. 2008. Dissolved organic nitrogen uptake by seagrasses. Limnol. Oceanogr. 53: 542-548. doi:10.4319/lo.2008.53.2.0542

Waycott, M., C. M. et al. 2009. Accelerating loss of seagrasses across the globe threatens coastal ecosystems. Proc. Natl. Acad. Sci. 106: 12377-12381. doi:10.1073/pnas.0905620106

Webb, J. E., and J. Theodor. 1972. Wave-induced circulation in submerged sands. J. Marine Biol. Assoc. UK. 52: 903914. doi:10.1017/S0025315400040649

Wu, F. C., W. S. Hsieh, and Y. J. Chou. 1999. Variation of roughness coefficients for unsubmerged and submerged vegetation. J. Hydraulic Eng. 125: 934-942. doi:10.1061/ (ASCE)0733-9429(1999)125:9(934)

\section{Acknowledgements}

This work was supported by a NWO WOTRO host fellowship for transfer of knowledge, WOTRO-WT-84-644. We thank Jos van Soelen, Bas Koutstaal, and Louie Haazen for invaluable technical assistance.

\section{Conflict of Interest}

None declared.

Submitted 16 April 2015 Revised 08 January 2016; 06 May 2016; 21 June 2016 Accepted 22 June 2016 Associate editor: Josef Ackerman 